\title{
PENGARUH MODEL PEMBELAJARAN INKUIRI TERBIMBING TERHADAP KETERAMPILAN PROSES SAINS PESERTA DIDIK KELAS XI SMA NEGERI 2 MAJENE
}

\section{THE EFFECT OF GUIDED INQUIRY LEARNING MODEL ON SCIENCE PROCESS SKILLS OF THE XI CLASS STUDENTS AT SMA NEGERI 2 MAJENE}

\author{
1) Zam'ah, ${ }^{2)}$ A. J. Patandean, ${ }^{3)}$ Bunga Dara Amin \\ Universitas Negeri Makassar \\ Kampus UNM Parangtambung Jln. Daeng Tata Raya, Makassar, 90224 \\ 1) e-mail : zealouszamah@gmail.com
}

\begin{abstract}
Abstrak. Pengaruh Model Pembelajaran Inkuiri Terbimbing Terhadap Keterampilan Proses Sains Peserta Didik Kelas Xi Sma Negeri 2 Majene. Penelitian ini merupakan penelitian quasi eksperiment dengan desain posttest only none equivalent control group design. Penelitian ini bertujuan untuk mendeskripsikan keterampilan proses sains peserta didik serta untuk menganalisis perbedaan keterampilan proses sains peserta didik pada kelas eksperimen dan kelas kontrol. Penelitian ini dilaksanakan di SMA Negeri 2 Majene tahun akademik 2018/2019 dan mengambil XI MIPA sebagai sampel, yaitu kelas experimen XI MIPA 3 sebanyak 30 siswa dan kelas XI MIPA 5 sebanyak 32 siswa sebagai kelas kontrol. Pemilihan sampel dilakukan dengan purposive sampling. Pada kelas eksperimen diterapkan pembelajaran inkuiri terbimbing dan kelas kontrol pembelajaran dilaksanakan secara konvensional. Hasil tes keterampilan proses sains diperoleh skor rata-rata pada kelas eksperimen yaitu 18,133 dengan kategori sedang, sedangkan pada kelas kontrol skor rata-rata yaitu 7,061 dengan kategori sangat rendah. Hasil uji statistik menggunakan uji t diperoleh bahwa $\mathrm{H}_{1}$ diterima dan $\mathrm{H}_{\mathrm{O}}$ ditolak. Dengan demikian dapat disimpulkan bahwa terdapat perbedaan keterampilan proses sains antara peserta didik yang diajar dengan pembelajaran menggunakan model inkuiri terbimbing dengan yang diajar secara konvensional.
\end{abstract}

Kata kunci : Model Pembelajaran Inkuiri Terbimbing, Keterampilan Proses Sains, XI MIPA

Abstract. The Effect Of Guided Inquiry Learning Model On Science Process Skills Of The Xi Class Students At Sma Negeri 2 Majene. This research is a quasi-experiment research with posttest only none quvalent control group design. This research aims to describe the science process skills of students and to analyze the differences in science process skills of students in the experimental class and the control class. This research was held at SMA Negeri 2 Majene academic year 2018/2019 and take XI MIPA as sample, that was XI MIPA 3 as experimental class, total 30 students, and XI MIPA 5, total 32 students as the control class. Sample selection was done by purposive sampling. In the experimental class applied guided inquiry learning and learning control classes were carried out conventionally. The results of the science process skills test obtained an average score in the experimental class of 19.367 with a medium category, while in the control class the average score was 7,061 with a very low category. The results of statistical tests using the t test were obtained that $H_{1}$ was accepted and $H_{O}$ was rejected. Thus it can be concluded that there are differences in science process skills between students taught by learning using a guided inquiry model with those taught conventional way.

Keywords : Guided Inquiry Learning Model, Science Process Skills, XI MIPA

\section{PENDAHULUAN}

Penerapan kurikulum 2013 dalam proses pembelajaran diatur dalam Permendikbud Nomor 103 Tahun 2014 yang bertujuan untuk mengembangkan 3 ranah yang sudah melekat pada diri peserta didik, yakni afektif (sikap), psikomotorik (keterampilan) dan kognitif (pengetahuan).
Proses pembelajaran yang berlangsung dalam kurikulum 2013 secara umum dapat mengembangkan potensi yang dimiliki peserta didik menjadi semakin meningkat melalui pendekatan ilmiah.

Pembelajaran IPA khususnya mata pelajaran Fisika merupakan pembelajaran yang menerapkan pendekatan ilmiah. Pada 
mata pelajaran Fisika terdapat banyak fenomena, peristiwa, dan fakta yang dapat ditemukan dan diselidiki dengan menggunakan keterampilan proses sains. Seperti halnya yang diungkapkan oleh Gagne (Wartono, 2003) bahwa dengan mengembangkan keterampilan proses sains anak dibuat kreatif, peserta didik akan mampu mempelajari IPA ditingkat yang lebih tinggi dalam waktu yang sangat singkat. Dengan demikian keterampilan proses sains sangat dibutuhkan dalam mempelajari Fisika.

Keterampilan-keterampilan proses sains adalah keterampilan-keterampilan yang dipelajari siswa pada saat mereka melakukan inquiri. Pada saat mereka terlibat aktif dalam penyelidikan ilmiah, mereka menggunakan berbagai macam keterampilan proses, bukan hanya satu metode ilmiah tunggal. (Khaeruddin \& Sujiono, 2005). Menurut Rustaman (2005) keterampilan proses sains dibangun dari tiga keterampilan yaitu, keterampilan kognitif atau intelektual, manual dan sosial. Keterampilan proses sains dikembangkan bersama-sama dengan fakta-fakta, konsep-konsep, dan prinsipprinsip sains

Pendekatan Keterampilan Proses Sains (KPS) dapat diartikan sebagai wawasan atau panutan pengembangan keterampilan-keterampilan, sosial, dan fisik yang bersumber dari kemampuankemampuan mendasar yang pada prinsipnya ialah ada dalam diri siswa. Senada dengan hal tersebut, Kurniati (2001) mengugkapkan bahwa pendekatan keterampilan proses sains adalah pendekatan yang memberi kesempatan kepada siswa agar dapat menemukan fakta membangun konsep-konsep, melalui kegiatan dan atau pengalaman-pengalaman seperti ilmuwan (Tawil, 2014).

Hasil kunjungan yang dilakukan di SMA Negeri 2 Majene, proses pembelajaran fisika yang diberlakukan merujuk pada tahapan pembelajaran langsung. Model pembelajaran ini masih cenderung bersifat teacher-centered dan kurang melibatkan peserta didik dalam menemukan suatu konsep. Pada kondisi pembelajaran seperti ini, peserta didik lebih memilih menghafal rumus tanpa mengetahui proses maupun sikap dari konsep fisika yang diperoleh. Secara tidak langsung, peserta didik menerima pembelajaran secara pasif dan mengakibatkan keterampilan proses sains yang melibatkan keterampilan kognitif, afektif dan psikomotor tidak berkembang.

Berdasarkan tuntutan Kurikulum 2013 dan mengingat pentingnya keterampilan proses sains hendaknya dilakukan proses pembelajaran yang berorientasi pada peserta didik aktif (student-centered), sehingga memberikan keleluasaan kepada peserta didik untuk melakukan aspek-aspek keterampilan proses sains. Oleh karena itu, diperlukan model pembelajaran yang dapat memfasilitasi terselenggaranya kegiatan pembelajaran yang melibatkan keaktifan peserta didik.

Adapun menurut Moore (2005) dalam Sujarwo (2011) pembelajaran inkuiri memiliki tiga tingkatan yaitu:

a. Guided Inquiry (inkuiri terbimbing) 
Suatu kegiatan pembelajaran yang di dalamnya pemilihan masalah masih ditentukan oleh pendidik dengan menggunakan teknik bertanya.

b. Modified Free Inquiry (inkuiri dimodifikasi)

Suatu proses pembelajaran seperti inkuiri bebas tetapi topik permasalahannya ditentukan oleh pendidik.

c. Free Inquiry (inkuiri bebas)

Suatu proses pembelajaran yang memberi kebebabsan kepada peserta didik untuk menemukan masalahnya sendiri, merancang eksperimen sampai mencari kesimpulan.

Salah satu model pembelajaran yang mengacu pada kurikulum 2013 dan dapat digunakan adalah model pembelajaran inkuiri. Model pembelajaran inkuiri terbimbing merupakan salah satu tingkatan model pembelajaran inkuiri yang sesuai dengan tingkat berpikir peserta didik tingkat SLTA, dimana peserta didik belum terlatih untuk menemukan konsep sendiri sehingga dibutuhkan tahapan-tahapan yang dapat mengarahkan peserta didik.

Menurut Khoirul (2015), tahap inkuiri terbimbing yaitu siswa bekerja (bukan hanya duduk, mendengarkan lalu menulis) untuk menemukan jawaban terhadap masalah yang dikemukakan oleh guru di bawah bimbingan yang intensif dari guru. Tugas guru lebih seperti "memancing" siswa untuk melakukan sesuatu. Guru datang ke kelas dengan membawa masalah untuk dipecahkan oleh siswa, kemudian mereka dibimbing untuk menemukan cara terbaik dalam memecahkan masalah tersebut.

Kelebihan model inkuiri terbimbing adalah guru mampu membimbing siswa melakukan kegiatan dengan memberi pertanyaan awal dan mengarahkan pada suatu diskusi. Guru mempunyai peran aktif dalam menentukan permasalahan dan tahap-tahap pemecahannya. Inkuiri terbimbing ini digunakan bagi siswa yang kurang berpengalaman dalam pembelajaran inkuiri. Melalui pembelajaran model inkuiri siswa belajar berorientasi pada bimbingan dan petunjuk dari guru hingga siswa dapat memahami konsep-konsep pelajaran, dan dengan model tersebut siswa tidak mudah bingung (Dewi dkk, 2013).

Tujuan yang ingin dicapai dalam penelitian ini adalah untuk mendeskripsikan skor keterampilan proses sains peserta didik kelas XI SMA Negeri 2 Majene yang diajar dengan menggunakan model pembelajaran inkuiri terbimbing dan yang diajar secara konvensional, serta untuk menganalisis perbedaan keterampilan proses sains peserta didik kelas XI SMA Negeri 2 Majene yang diajar menggunakan model pembelajaran inkuiri terbimbing dan diajar secara konvensional

\section{METODE}

Penelitian ini menggunakan jenis penelitian Quasi Eksperimetal dengan desain Posttest Only Non Equvalent Control group Design yang dilaksanakan di SMA Negeri 2 Majene, pada semester ganjil tahun ajaran 2018/2019. Sampel 
pada penelitian ini diambil menggunakan purposive sampling, berdasarkan pertimbangan sebagai berikut: (a) peserta didik pada kelas eksperimen dan kelas kontrol merupakan peserta didik yang aktif; (b) peserta didik kelas eksperimen dan kelas kontrol memiliki kemampuan berinkuiri. Sehingga terpilih peserta didik pada kelas XI MIPA 3 sebagai kelas eksperimen yang diajar dengan menggunakan model pembelajaran inkuiri terbimbing dan kelas XI MIPA 5 sebagai kelas kontrol yang diajar dengan model pembelajaran konvensional.

Instrumen dan perangkat penelitian yang digunakan dalam penelitian ini adalah instrumen tes keterampilan proses sains yang berbentuk uraian serta RPP dan LKPD tentang materi Elastisitas dan Hukum Hooke. Tahap persiapan diawali dengan observasi di sekolah, menyusun perangkat pembelajaran dan instrumen yang kemudian diavlidasi. Tahap pelaksanaan berlangsung pada proses pembelajaran yang dilanjutkan dengan pemberian tes keterampilan proses sains setelah materi selesai. Tahap akhir dilakukan dengan menyusun laporan hasil penelitian.

\section{HASIL DAN PEMBAHASAN}

Hasil penelitian ini menunjukkan gambaran tentang skor keterampilan proses sains peserta didik kelas XI IPA 3 yang diajar dengan menggunakan model pembelajaran inkuiri terbimbing dan kelas XI IPA 5 yang diajar dengan menggunakan model pembelajaran konvensional yang dapat dilihat pada Tabel 4.1.

\section{Tabel 1. Statistik Skor Keterampilan Proses Sains Peseta Secara Umum}

\begin{tabular}{lcc}
\hline \multirow{2}{*}{ Statistik } & \multicolumn{2}{c}{ Keterampilan Proses Sains } \\
\cline { 2 - 3 } & Eksperimen & Kontrol \\
\hline Ukuran sampel & 30 & 33 \\
Skor ideal maksimum & 40 & 40 \\
Skor ideal minimum & 0 & 0 \\
Skor tertinggi & 34 & 19 \\
Skro terendah & 6 & 0 \\
Skor rata-rata & 18,133 & 7,061 \\
Standar Deviasi & 6,75 & 5,11 \\
Varians & 45,568 & 26,121 \\
\hline
\end{tabular}

Tabel 1 menunjukkan bahwa perolehan

Gambaran pengkategorian skor skor rata-rata, standar deviasi dan varians keterampilan proses sains fisika peserta peserta didik kelas eksperimen lebih tinggi didik kelas eksperimen dan kelas kontrol dibandingkan dengan skor kelas kontrol. disusun pada Tabel 2 
Tabel 2. Distribusi Frekuensi Pengkategorian Skor Posttest Keterampilan Proses Sains Secara Umum

\begin{tabular}{cccccc}
\hline \multirow{2}{*}{$\begin{array}{c}\text { Persentase } \\
(\boldsymbol{\%})\end{array}$} & Kategori & Frekuensi & $\begin{array}{c}\text { Persentase } \\
(\boldsymbol{\%})\end{array}$ & Frekuensi & $\begin{array}{c}\text { Persentase } \\
(\boldsymbol{\%})\end{array}$ \\
\cline { 3 - 6 } & & 2 & 6,67 & 21 & 63,63 \\
$0-20$ & Sangat rendah & 13 & 43,33 & 11 & 33,33 \\
$21-40$ & Rendah & 8 & 26,67 & 1 & 3,03 \\
$41-60$ & Sedang & 6 & 20 & 0 & 0 \\
$61-80$ & Tinggi & 1 & 3,33 & 0 & 0 \\
$81-100$ & Sangat tinggi & 30 & 100 & 33 & 100 \\
\hline \multicolumn{2}{c}{ Jumlah } & & & &
\end{tabular}

Perolehan Tabel 2 menunjukkan bahwa skor keterampilan proses sains peserta didik kelas eksperimen lebih mendominasi pada kategori rendah dan jumlah peserta didik terendah berada pada kategori sangat tinggi. Lain halnya dengan kelas kontrol, peserta didik lebih mendominasi pada kategori sangat rendah dan jumlah peserta didik terendah pada kategori tinggi dan sangat tinggi.

Indikator keterampilan proses sains yang diukur meliputi indikator mengidentifikasi variabel, merumuskan hipotesis, merencanakan percobaan, menginterpretasi data, dan mengkomunikasikan. Pada instrumen yang digunakan, setiap indikator terdiri atas 2 nomor.

Hasil rekapitulasi skor keterampilan proses sains peserta didik kelas XI SMA Negeri 2 Majene untuk tiap indikator disajikan dalam grafik berikut.

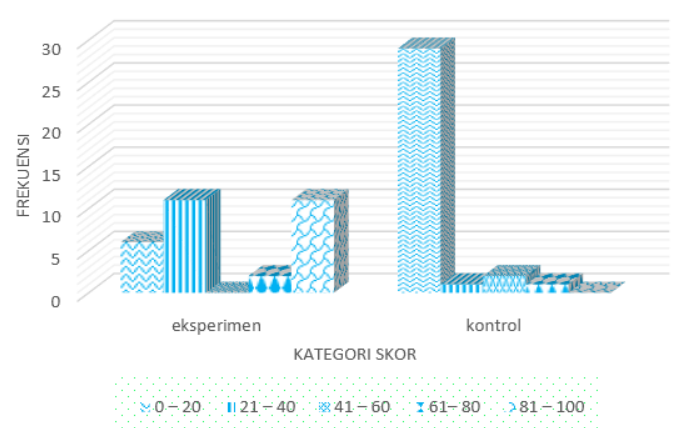

Gambar 1. Rekapitulasi Skor Keterampilan Proses Sains Peserta Didik Kelas Eksperimen dan Kelas Kontrol pada Indikator Mengidentifikasi Variabel

Pada Gambar 1 memuat gambaran hasil skor keterampilan proses sains pada indikator mengidentifikasi variabel yang memperlihatkan bahwa terdapat perbedaan anatara kelas eksperimen dan kelas kontrol. Peserta didik kelas kontrol dominan masih kurang dalam keterampilan proses sains indikator mengidentifikasi variabel. 


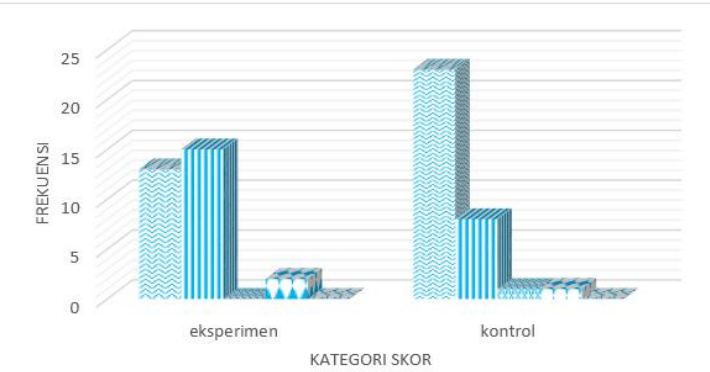

Gambar 2. Rekapitulasi Skor Keterampilan Proses Sains Peserta Didik Kelas Eksperimen dan Kelas Kontrol pada Indikator Merumuskan Hipotesis

Gambar 2 menunjukkan perbedaan yang tidak terlalu signifikan anatara kelas eksperimen dan kelas kontrol pada indikator merumuskan hipotesis. Peserta didik kelas eksperimen dan kelas kontrol dominan masih kurang pada indikator merumuskan hipotesis.

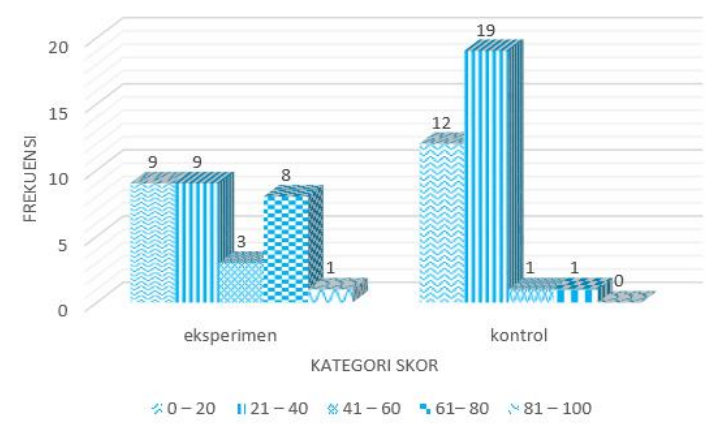

Gambar 3. Rekapitulasi Skor Keterampilan Proses Sains Peserta Didik Kelas Eksperimen dan Kelas Kontrol pada Indikator Merencanakan Percobaan

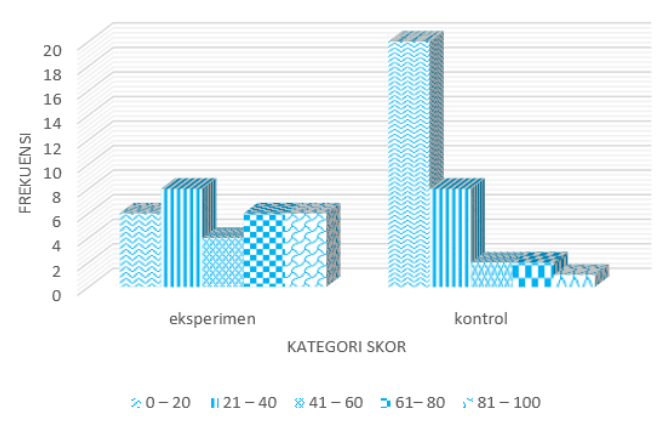

Gambar 4. Rekapitulasi Skor Keterampilan Proses Sains Peserta Didik Kelas Eksperimen dan Kelas Kontrol pada Indikator Menginterpretasi Data
Pada Gambar 3 dan Gambar 4 menunjukkan bahwa terdapat perbedaan anatara kelas eksperimen dan kelas kontrol. Peserta didik kelas kontrol dominan masih kurang dalam keterampilan proses sains indikator merencanakan percobaan dan menginterpretasi data.

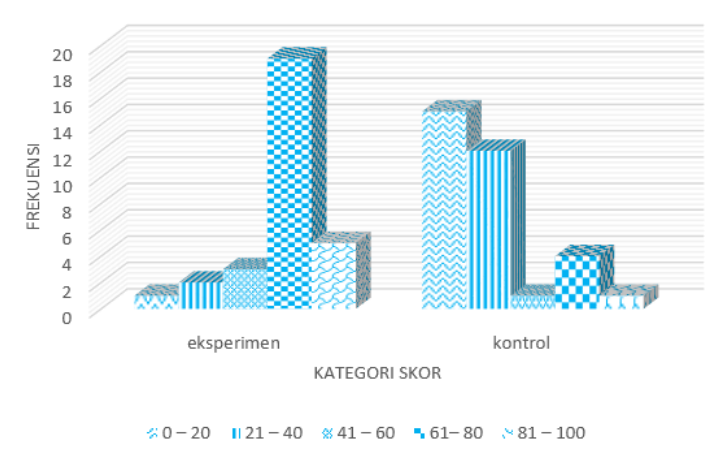

Gambar 5. Rekapitulasi Skor Keterampilan Proses Sains Peserta Didik Kelas Eksperimen dan Kelas Kontrol pada Indikator Mengkomunikasikan

Pada Gambar 5 menunjukkan bahwa terdapat perbedaan yang lebih menonjol antara kelas eksperimen dan kelas kontrol. Peserta didik kelas eksperimen dominan lebih meningkat, sedangkan peserta didik kelas kontrol dominan masih kurang pada indikator mengidentifikasi variabel.

Hasil perhitungan analisis inferensial menunjukkan bahwa skor keterampilan proses sains peserta didik kelas eksperimen dan kelas kontrol terdistribusi normal dan memiliki varians data yang homogen sehingga uji-t yang digunakan untuk menguji hipotesis penelitian adalah uji-t dua pihak dengan persamaan polled varians. Dalam pengujian hipotesis diperoleh diperoleh nilai $t_{\text {hitung }}$ sebesar 7,738 dengan $t_{\text {tabel }}$ hasil interpolasi yaitu 1,9997 sehingga $t_{\text {hitung }}>$ $\mathrm{t}_{\text {tabel }}$ maka $\mathrm{H}_{0}$ ditolak dan $\mathrm{H}_{1}$ diterima. Dengan demikian dapat disimpulkan bahwa terdapat perbedaan keterampilan proses sains antara peserta didik yang diajar dengan moedel pembelajaran inkuiri terbimbing dan yang diajar secara konvensional. 
Apabila pembelajaran model pembelajaran inkuiri terbimbing diterapkan pada populasi, skor keterampilan proses sains pada kelas eksperimen adalah 15,85 $<\mu<20,42$. Sehingga dapat disimpulkan bahwa model pembelajaran inkuiri terbimbing memberikan dampak lebih baik terhadap keterampilan proses sains peserta didik dibandingkan dengan pembelajaran secara konvensional

\section{SIMPULAN}

Berdasarkan hasil penelitian dan pembahasan, dapat disimpulkan sebagai berikut.

1. Skor keterampilan proses sains peserta didik kelas XI SMA Negeri 2 Majene yang diajar dengan menggunakan model pembelajaran

\section{DAFTAR RUJUKAN}

Dewi, N. L., Dantes, N., \& Sadia, I. W. 2013. Pengaruh Model Pembelajaran Inkuiri Terbimbing Terhadap Sikap Ilmiah Dan Hasil Belajar IPA. E-Journal Program Pascasarjana Universitas Pendidikan Ganesha. Volume: 3.

Khaeruddin, \& Sujiono, E. H. 2005. Pembelajaran Sains (IPA) Berdasarkan Kurikulum Berbasis Kompetensi. Makassar: State University of Makassar Press

Khoirul Anam, M.A., 2015. Pembelajaran Berbasis Inkuiri (Metode dan Aplikasi), inkuiri terbimbing berada pada kategori sedang.

2. Skor keterampilan proses sains peserta didik kelas XI SMA Negeri 2 Majene yang diajar secara konvensional berada pada kategori rendah.

3. Terdapat perbedaan keterampilan proses sains antara peserta didik kelas XI SMA Negeri 2 Majene yang diajar dengan pembelajaran inkuiri terbimbing dan yang diajar secara konvensional. Hal ini menunjukkan bahwa model pembelajaran inkuiri terbimbing dapat memberikan pengaruh terhadap keterampilan proses sains peserta didik

in Pembelajaran Berbasis Inkuiri (Metode dan Aplikasi). Yogyakarta: Pustaka Pelajar.

Rustaman, N. Y. (2005). Strategi Belajar Mengajar Biologi. Malang: Universitas Negeri Malang.

Sujarwo. 2011. Model-model Pembelajaran. Yogyakarta: Venus Gold Press

Tawil, M., \& Liliasari. (2014). Keterampilanketerampilan Sains dan Implementasinya Dalam Pembelajaran IPA. Makassar: Badan Penerbit Universitas Negeri Makassar. 